\title{
Powered by standards - new data tools for the climate sciences
}

\author{
Dr Andrew Woolf (Andrew.Woolf@stfc.ac.uk) \\ STFC Rutherford Appleton Lab, UK
}

EGU General Assmebly, Vienna, Splinter Session SPM23, 22-Apr-2009 


\section{Geog}

\section{temperature}

ERA40

The ECMWF ERA-40 Re-Analysis Project consists of a number of climate datasets spanning the period mid-1957 to August 2002 using a consistent model. The data overlaps with the earlier ECMWF ERA-15 Re-analysis project (1979-1993). The broad objectives and partner organisations are presented in the ERA-40 background information. badc.nerc.ac.uk air potential temperature

GridSeries (xypt)

European Synoptic stations

1990-1996

Hourly Surface data from 141 European stations for the period 19901996. Parameters include temperature, wind, rainfall, cloud cover etc.

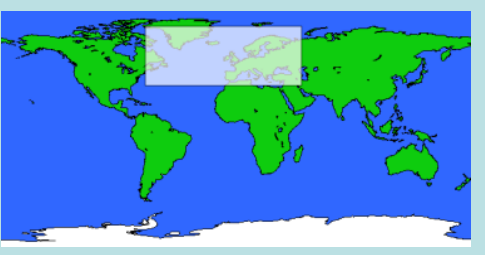




\section{temperature}

ERA40

The ECMWF ERA-40 Re-Analysis Project consists of a number of climate datasets spanning the period mid-1957 to August 2002 using a consistent model. The data overlaps with the earlier ECMWF ERA-15 Re-analysis project (1979-1993). The broad objectives and partner organisations are presented in the ERA-40 background information. badc.nerc.ac.uk air potential temperature

GridSeries (xypt)

\section{European Synoptic stations}

1990-1996

Hourly Surface data from 141 European stations for the period 19901996. Parameters include temperature, wind, rainfall, cloud cover etc.

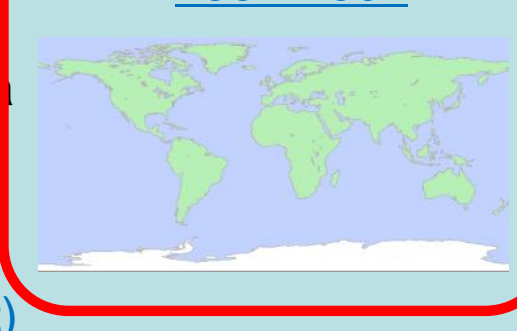




\section{temperature}

ERA40

The ECMWF ERA-40 Re-Analysis Project consists of a number of

ISO 19115 EX Extent climate datasets spanning the period mid-1957 to August 2002 using a consistent model. The data overlaps with the earlier ECMWF ERA-15 Re-analysis project (1979-1993). The broad objectives and partner organisations are procontod in tho ERA 10 background information. badc.nerc.ac.uk air potential temperature GridSeries (xypt)

\section{ISO 19115 MD_Keywords}

\section{European Synoptic stations}

\section{0-1996}

Hourly Surface data from 141 European stations for the period 19901996. Parameters include temperature, wind, rainfall, cloud cover etc.

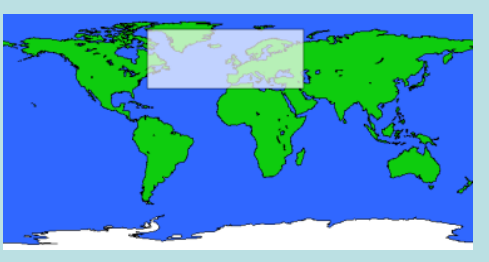




\section{Geoge temperature}

\section{thesaurusName: $\mathbf{C F}$ definition}

Re-Analysis Project consists of a number of

ISO 19115 EX Extent hing the period mid-1957 to August 2002 using a data overlaps with the earlier ECMWF ERA-15

Re-analystor (1979-1993). The broad objectives and partner organisations are procontod in tho ERA 10 bgckground information.

badc.nerc.ac.uk air potential temperature GridSeries (xypt)

\section{$\underline{1957-2002}$}

ISO 19115 MD_Keywords

\section{European Synoptic stations}

1990-1996

Hourly Surface data from 141 European stations for the period 19901996. Parameters include temperature, wind, rainfall, cloud cover etc.

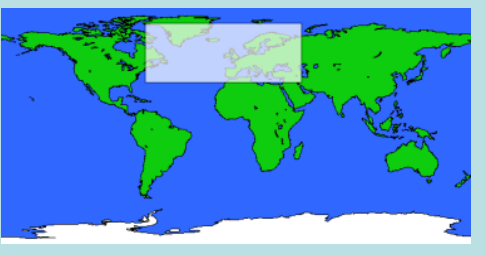




\section{temperature}

\section{thesaurusName: $\mathbf{C F}$ definition}

ISO 19126 ("Feature concept dictionary and registers")

Re-ISO 19135 ("Procedures for ing dat item registration")

Re-analysisop (1979-1993). The broad objectives and partner organisations areprosontod in tho ERA 10 bzackground information. badc.nerc.ac.uk air potential temperature GridSeries (xypt)

ISO 19115 MD_Keywords

European Synoptic stations

1990-1996

Hourly Surface data from 141 European stations for the period 19901996. Parameters include temperature, wind, rainfall, cloud cover etc.

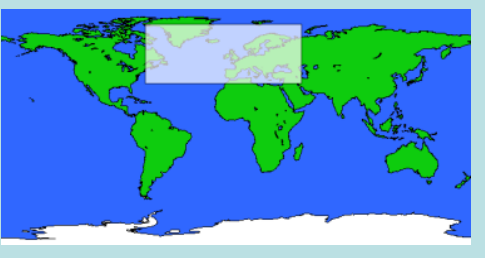




\begin{tabular}{|c|c|c|c|c|c|c|}
\hline \multicolumn{3}{|c|}{\begin{tabular}{|c|l}
$\vdots^{* *} \vdots$ & European Commission \\
$\vdots$ & Joint Research Centre
\end{tabular}} & RE Registry - Version 1.00 & \multicolumn{3}{|c|}{$\begin{array}{l}\text { Search Contact Legal notice English (en) } \\
\text { INSPIRE } \\
\text { registry }\end{array}$} \\
\hline \multicolumn{7}{|c|}{ Europa > European Commission > JRC > INSPIRE Registry } \\
\hline $\begin{array}{l}\text { Tuesday, } 21 \text { April } 2009 \\
\text { Not logged in }\end{array}$ & \multicolumn{6}{|c|}{$\begin{array}{c}\text { Feature Concept Dictionary } \\
\text { View Register Items }\end{array}$} \\
\hline \multirow{30}{*}{$\begin{array}{l}\text { Registry Home } \\
\text { Registers } \\
\begin{aligned} \text { Geature Concept } \\
\frac{\text { Deationary }}{\text { Dictions }} \\
\underline{\text { Items }} \\
\underline{\text { Glossary }} \\
\underline{\text { Items }}\end{aligned}\end{array}$} & Valid & Superseded & Retired & & & \\
\hline & 圆: Idem & 目 Item Class & 目 & 目 Status & 目 ${ }_{\text {Accepted }}^{\text {Date }}$ & 圆 Date \\
\hline & 1 & theme & Coordinate reference systems & Valid & 05-Dec-08 & \\
\hline & 2 & theme & Geoaraphical arid systems & Valid & 05-Dec-08 & \\
\hline & 10 & theme & Elevation & Valid & $05-D e c-08$ & \\
\hline & 11 & theme & Land cover & Valid & 05-Dec-08 & \\
\hline & 12 & theme & Orthoimagery & Valid & $05-$ Dec-08 & \\
\hline & 13 & theme & Geology & Valid & $05-\mathrm{Dec}-08$ & \\
\hline & 14 & theme & Statistical units & Valid & $05-D e c-08$ & \\
\hline & 15 & theme & Buildinas & Valid & 05-Dec-08 & \\
\hline & 16 & theme & Soil & Valid & 05-Dec-08 & \\
\hline & 17 & theme & Land use & Valid & 05-Dec-08 & \\
\hline & 18 & theme & Human health and safety & Valid & $05-$ Dec-08 & \\
\hline & 19 & theme & Utility and qovernmental services & Valid & 05-Dec-08 & \\
\hline & 20 & theme & Environmental monitorina facilities & Valid & 05-Dec-08 & \\
\hline & 21 & theme & Production and industrial facilities & Valid & $05-D e c-08$ & \\
\hline & 22 & theme & Aqricultural and aquaculture facilities & Valid & 05-Dec-08 & \\
\hline & 23 & theme & Population distribution - demography & Valid & 05-Dec-08 & \\
\hline & 24 & theme & $\begin{array}{l}\text { Area manaqement/restriction/requlation } \\
\text { zones and reportinq units }\end{array}$ & Valid & 05-Dec-08 & \\
\hline & 25 & theme & Natural risk zones & Valid & 05-Dec-08 & \\
\hline & 26 & theme & Atmospheric conditions & Valid & 05-Dec-08 & \\
\hline & 27 & theme & Meteorological qeographical features & Valid & 05-Dec-08 & \\
\hline & 28 & theme & Oceanographic qeographical features & Valid & 05-Dec-08 & \\
\hline & 29 & theme & Sea reqions & Valid & 05-Dec-08 & \\
\hline & 30 & theme & Bio-qeographical reqions & Valid & 05-Dec-08 & \\
\hline & 31 & theme & Habitats and biotopes & Valid & 05-Dec-08 & \\
\hline & 32 & theme & Species distribution & Valid & 05-Dec-08 & \\
\hline & 33 & theme & Eneray resources & Valid & 05-Dec-08 & \\
\hline & 34 & theme & Mineral resources & Valid & 05-Dec-08 & \\
\hline & 38 & spatial object type & Administrative unit upper level & Valid & 05-Dec-08 & \\
\hline
\end{tabular}




\section{Geog}

\section{temperature}

ERA40

The ECMWF ERA-40 Re-Analysis Project consists of a number of climate datasets spanning the period mid-1957 to August 2002 using a consistent model. The data overlaps with the earlier ECMWF ERA-15

Re-analysis project (1979-1993). The broad objectives and partner organisations are presented in the ERA-40 background information. badc.nerc.ac.uk air potential temperature GridSerie: (xypt) ISO 19115 MD_ReferenceSystem

\section{European Synoptic stations}

1990-1996

Hourly Surface data from 141 European stations for the period 19901996. Parameters include temperature, wind, rainfall, cloud cover etc.

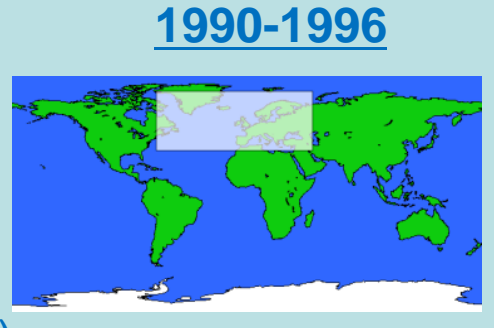




\section{Geog}

\section{temperature}

ERA40

The ECMWF ERA-4 climate datasets spa consistent model. Th

authority: BADC definition of a number of ugust 2002 using a ECMWF ERA-15

Re-analysis project (1979-1993). The broand tives and partner organisations are presented in the ERA-40 backgroumanfermation. badc.nerc.ac.uk air potential temperature GridSento- (xypt)

ISO 19115 MD_ReferenceSystem

European Synoptic stations

1990-1996

Hourly Surface data from 141 European stations for the period 19901996. Parameters include temperature, wind, rainfall, cloud cover etc.

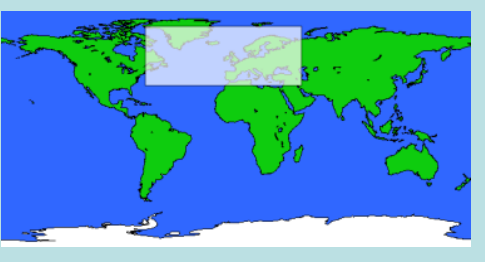




\section{Geog}

\section{temperature}

ERA40

The ECMWF ERA-4 climate datasets spa consistent model. Th authority: BADC definition

Re-analysis project (1979-1993). The broand tives and partner organisations are presented in the ERA-40 backgroum information. badc.nerc.ac.uk air potential temperature GridSento- (xypt)

ISO 19115 MD_ReferenceSystem

European Synoptic stations

1990-1996

Hourly Surface data from 141 European stations for the period 19901996. Parameters include temperature, wind, rainfall, cloud cover etc.

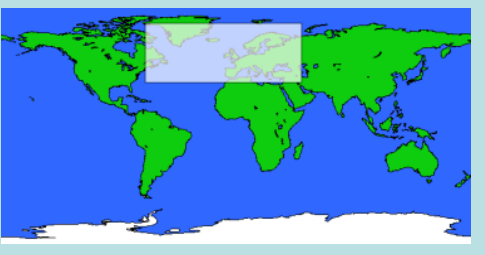




\section{ISO 19111-2}

- Proposed by UK as NWIP late 2006

- DIS voted for publication this year!
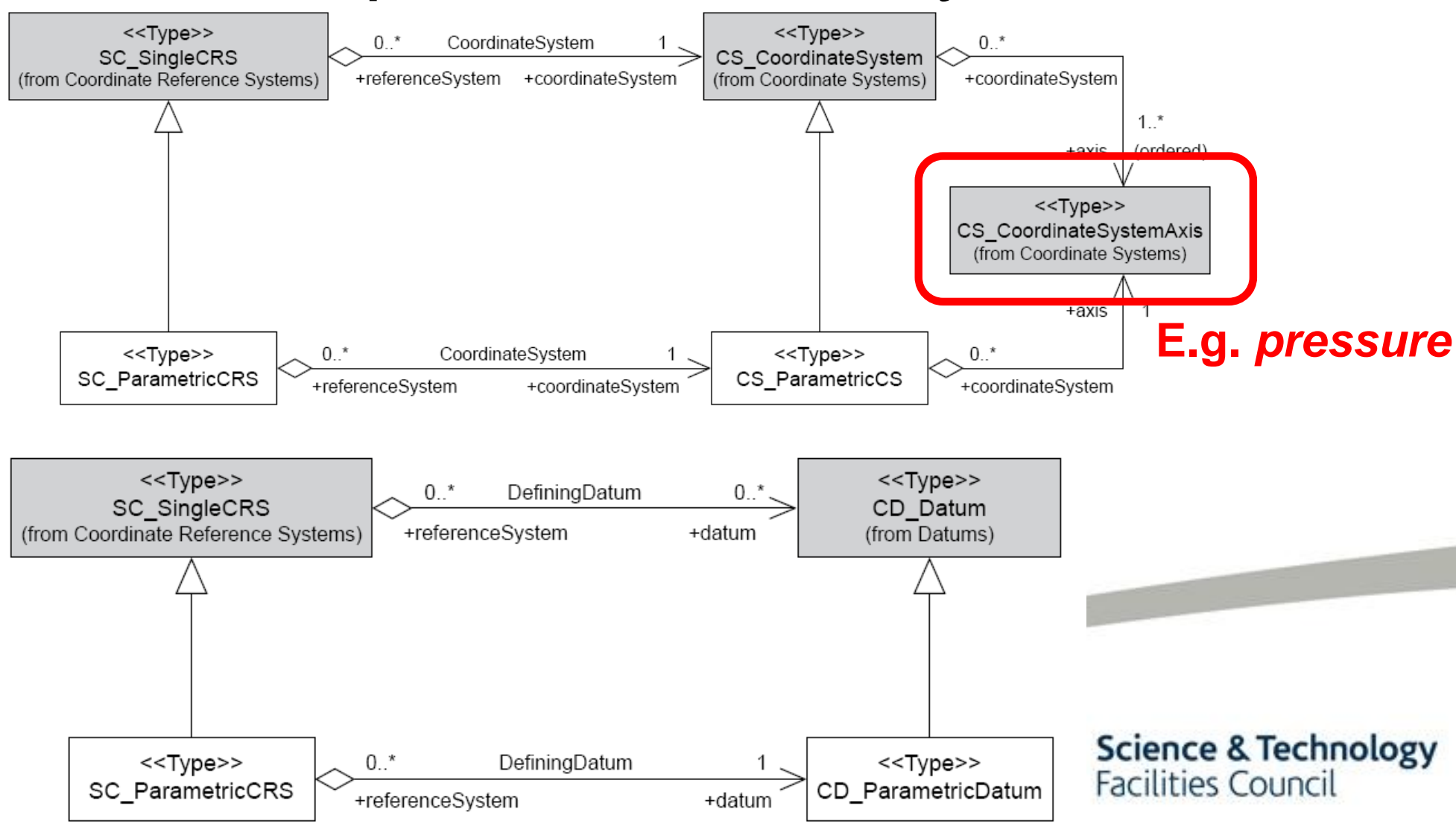

Science \& Technology Facilities Council 


\section{ISO 19111-2}

- datum: parameter or set of parameters that define the position of the origin, the scale, and the orientation of a coordinate system (ISO 19111)

- parametric datum: datum describing the relationship of a parametric coordinate system to an object. NOTE: The object is normally the Earth. (ISO 191112)

- Could have been more imaginative with parametric datum!

- e.g. full atmospheric density field... 


\section{Geog}

\section{temperature}

ERA40

The ECMWF ERA-40 Re-Analysis Project consists of a number of climate datasets spanning the period mid-1957 to August 2002 using a consistent model. The data overlaps with the earlier ECMWF ERA-15 Re-analysis project (1979-1993). The broad objectives and partner organisations are presented in the ERA-40 background information. badc.nerc.ac.uk air potential temperature GridSeries xypt)

\section{ISO 19115 MD_Contentlnformation}

\section{European Synoptic stations}

1990-1996

Hourly Surface data from 141 European stations for the period 19901996. Parameters include temperature, wind, rainfall, cloud cover etc.

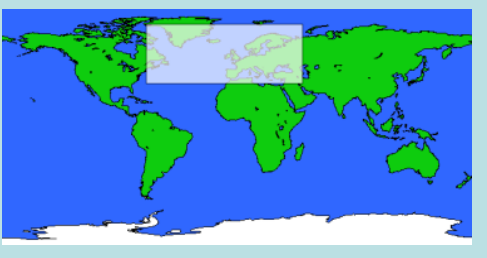




\section{Geog}

\section{temperature}

\section{ERA40 featureCatalogue: CSML clim featureType \\ con}

Re-analysis project (1979-1993). Tro of a number of ugust 2002 using a ECMWF ERA-15

and partner badc.nerc.ac.uk air potential temperature

\section{ISO 19115 MD_ContentInformation}

\section{European Synoptic stations}

1990-1996

Hourly Surface data from 141 European stations for the period 19901996. Parameters include temperature, wind, rainfall, cloud cover etc.

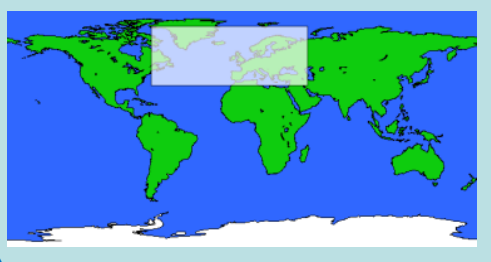




\section{Geog}

\section{temperature}

\section{ERA40 featureCatalogue: CSML clim featureType \\ con}

Re-analysis project (1979-1993). Itro ECiectives a for feature cataloguing")

organisations are presented in the ERA-40Dar yround information.

badc.nerc.ac.uk air potential temperature

of a number of ugus ISO 19110 ("Methodology

\section{ISO 19115 MD_ContentInformation}

European Synoptic stations

1990-1996

Hourly Surface data from 141 European stations for the period 1990-

1996. Parameters include temperature, wind, rainfall, cloud cover etc.

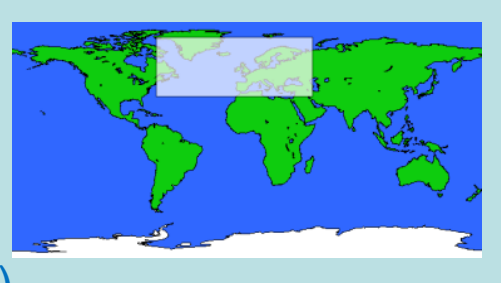




\section{Climate Science Modelling Language (CSML)}

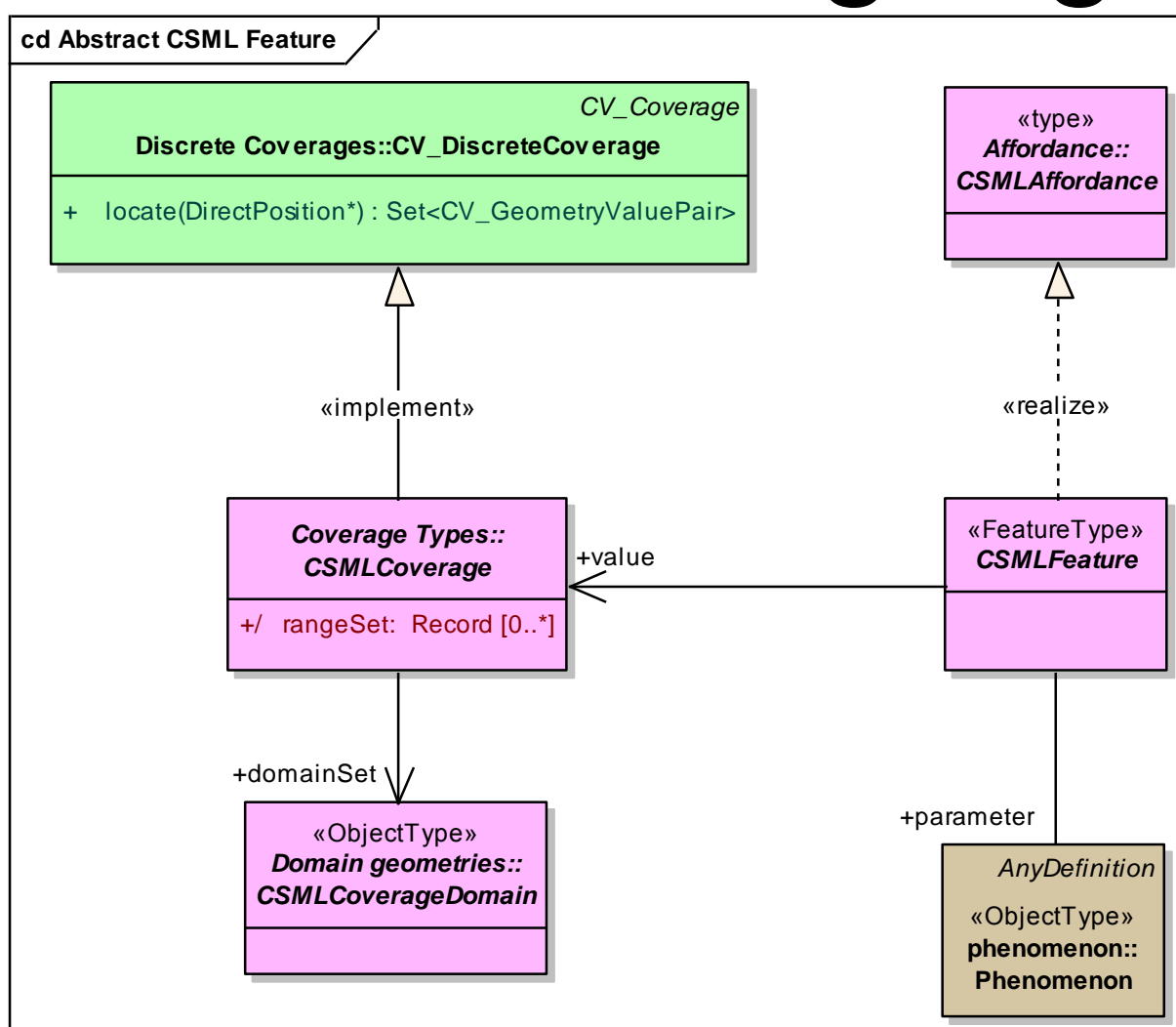

\section{RaggedSectionFeature}

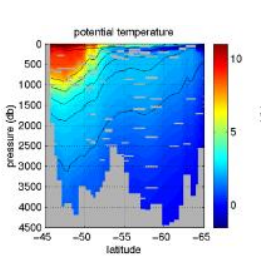

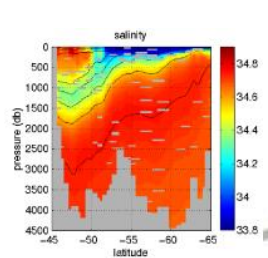

ScanningRadarFeature

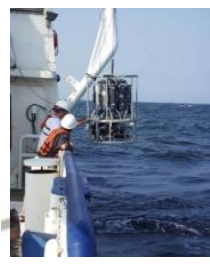

ProfileFeature
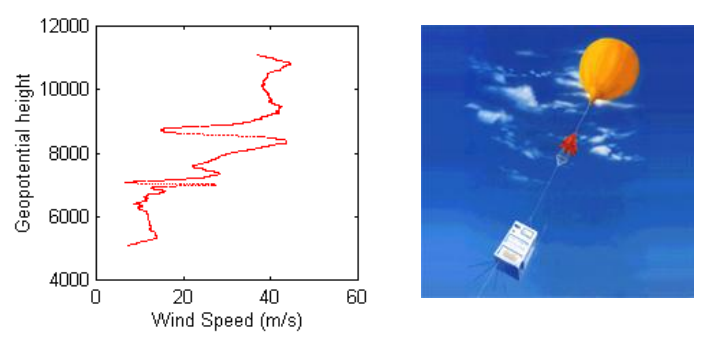

GridFeature
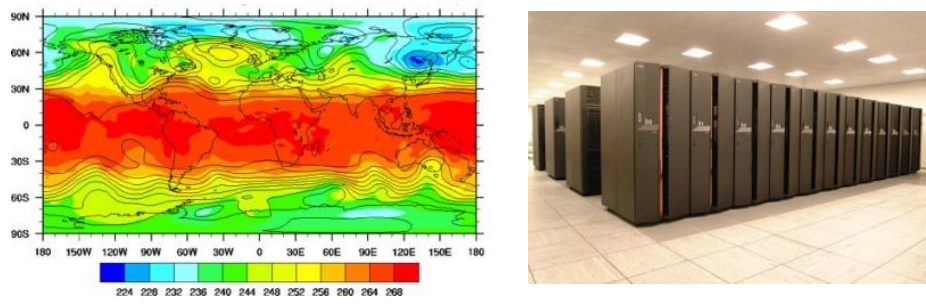

ProfileSeriesFeature

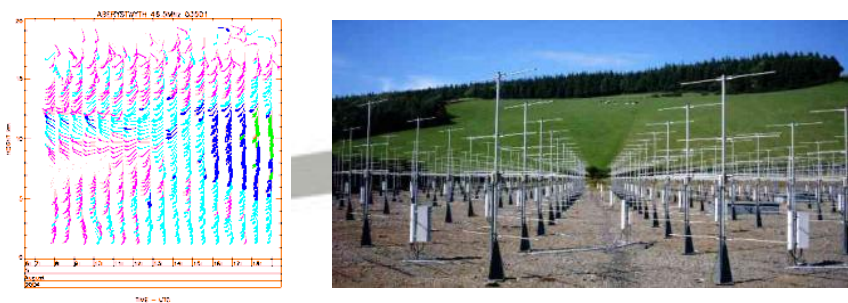

Science \& Technology Facilities Council 


\section{Climate Science Modelling Language (CSML)}

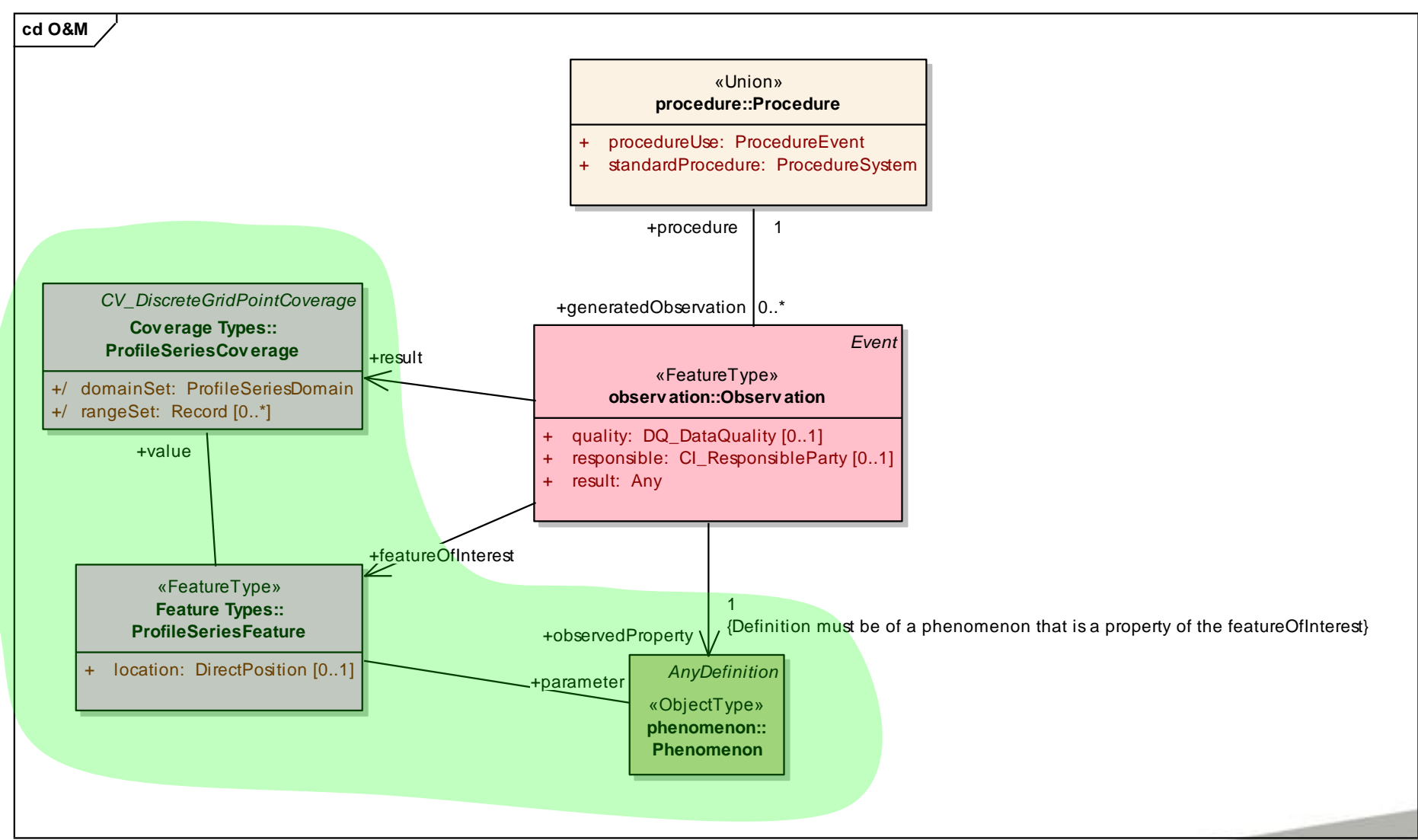

$\cdot O \& M$

'Sampling

Features' informed by CSML

-CSML v3 will specialise SF

-SF-coverage pattern documented in ISO 19156?

An Observation is an Event whose result is an estimate of the value of some Property of the Featureof-interest, obtained using a specified Procedure 


\section{ISO 19110 Feature Catalogue}

- EU FP6 project 'MOTIIVE'

- developed ebRIM-based Feature Catalogue

OGC 07-172,

'Feature Type

Catalogue

Extension

package' link 


\section{ISO 19110 Feature Catalogue}

- EU FP6 project 'MOTIIVE'

- developed ebRIM-based Feature Catalogue

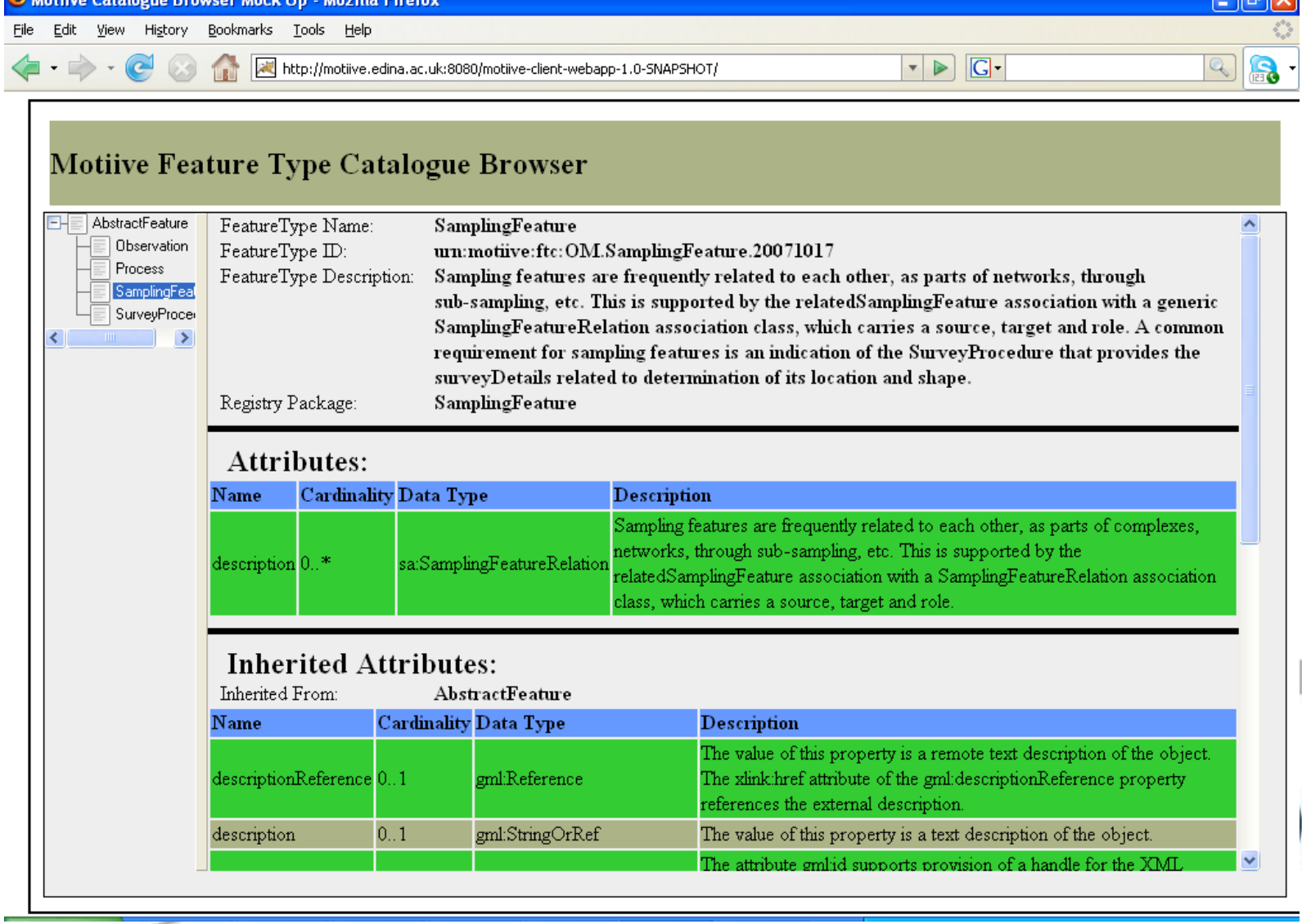

OGC 07-172,

'Feature Type

Catalogue

Extension

package' link

Science \& Technology Facilities Council 


\section{ISO 19110 Feature Catalogue}

- EU FP6 project 'MOTIIVE'

- developed ebRIM-based Feature Catalogue

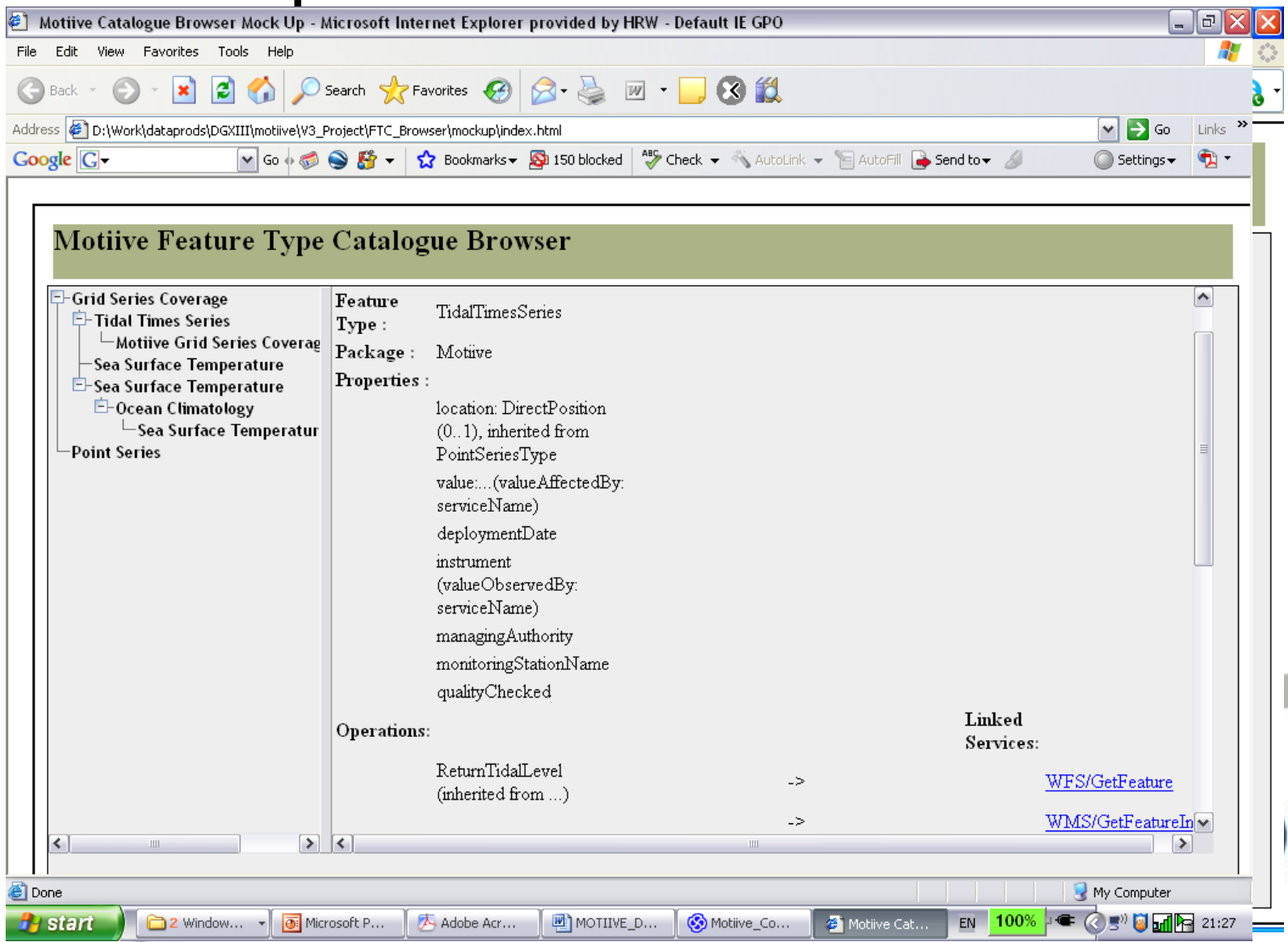

OGC 07-172,

'Feature Type

Catalogue

Extension

package' link

Science \& Technology Facilities Council 


\section{Geog}

\section{temperature}

ERA40 ISO 19115 Cl_OnlineResource

The ECMWF ERA-40 Re-Analysis Project consists of a number of climate datasets spanning the period mid-1957 to August 2002 using a consistent model. The data overlaps with the earlier ECMWF ERA-15 Re-analysis project (1979-1993). The broad objectives and partner organisations are presented in the ERA-40 background information.

\section{European Synoptic stations}

1990-1996

Hourly Surface data from 141 European stations for the period 19901996. Parameters include temperature, wind, rainfall, cloud cover etc.

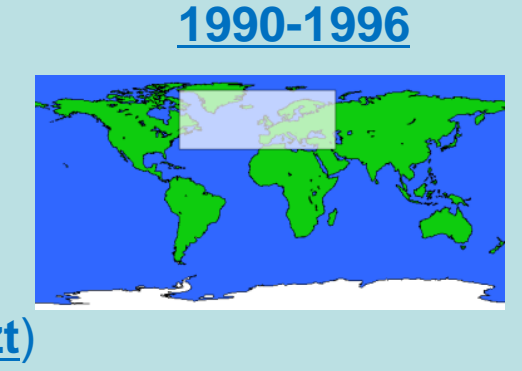




\section{Geog}

\section{temperature}

ERA40 ISO 19115 Cl_OnlineResource

Tne ECMWF ERA-40 Re-Analysis Project consists of a number of

ch te datasets spanning the period mid-1957 to August 2002 using a

cond model. The data overlaps with the earlier ECMWF ERA-15

Re-and ict (1979-1993). The broad objectives and partner

badc. applicationProfile: WFS ckground information. linkage: right click/copy

\section{European Synoptic stations}

1990-1996

Hourly Surface data from 141 European stations for the period 19901996. Parameters include temperature, wind, rainfall, cloud cover etc.

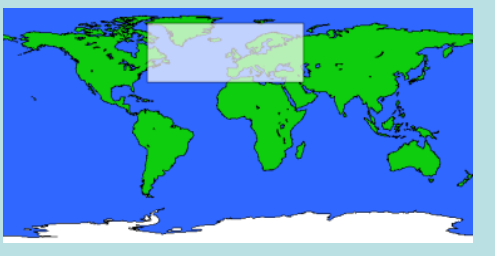




\section{Open tool $x x x$}

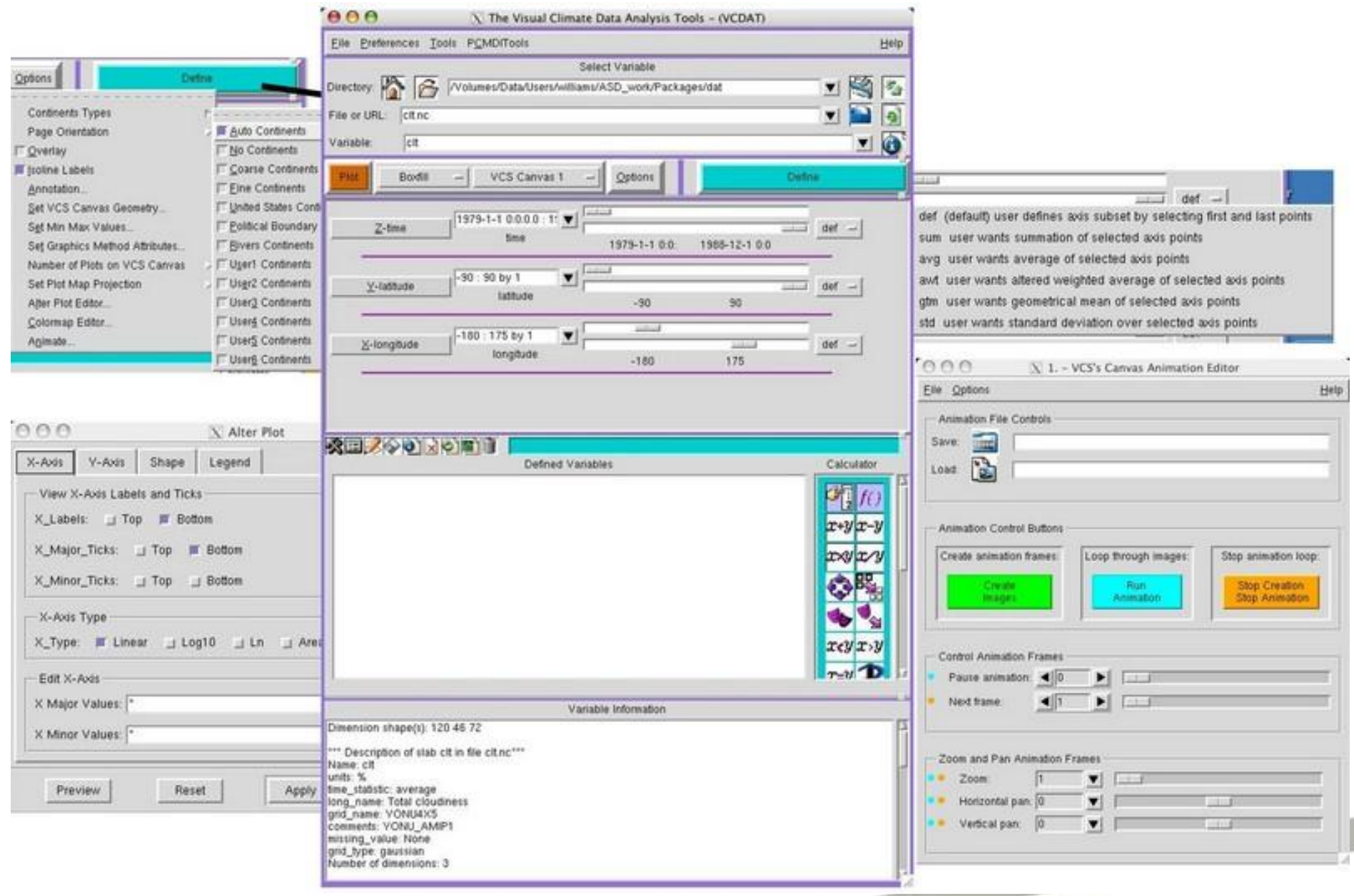

-http://portal.opengeospatial.org/files/?artifact_id=31487 -Lowe \& Woolf: EGU2009-10927, 18:30 Thursday 


\section{Open tool xxx}

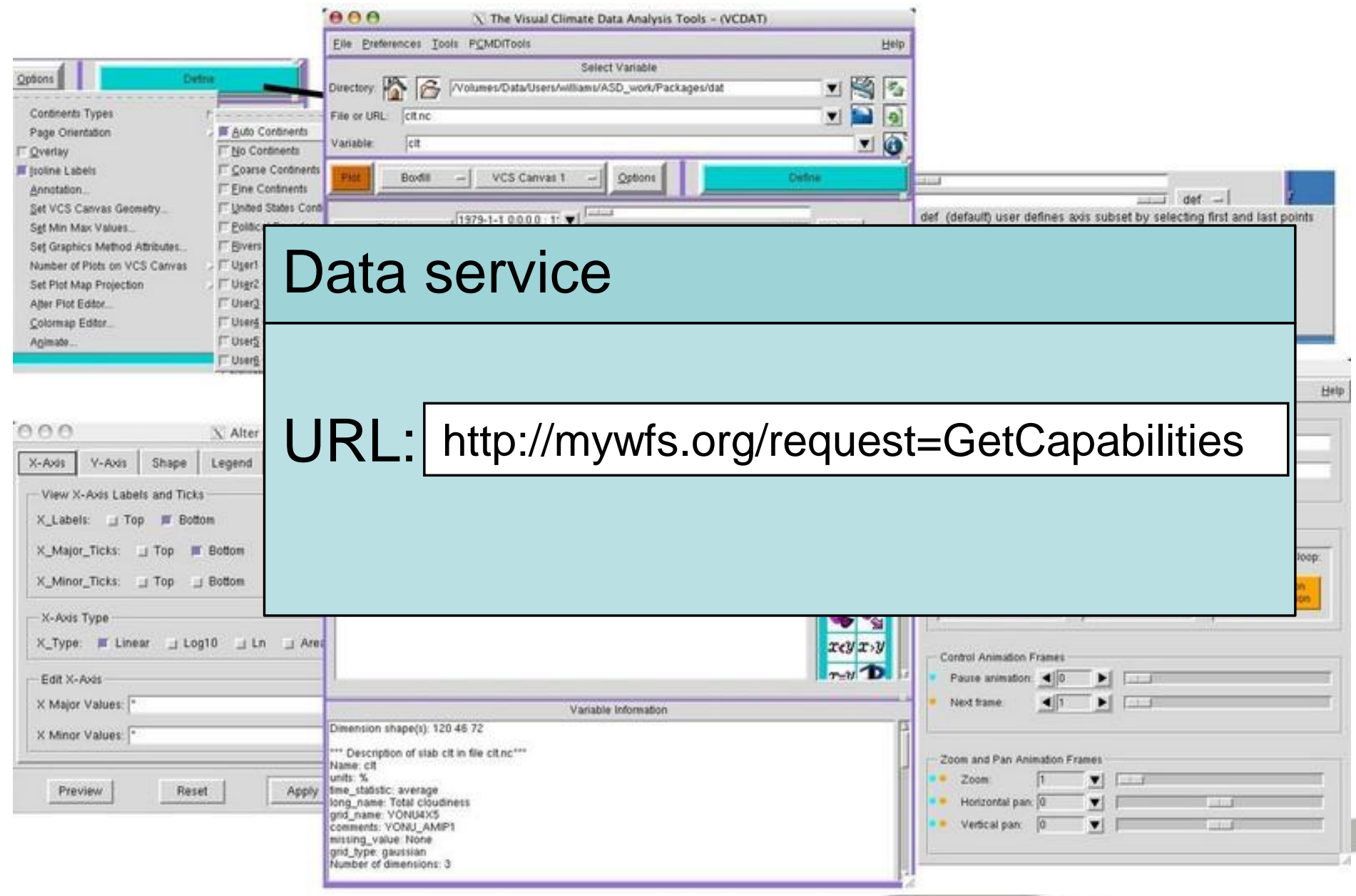

-http://portal.opengeospatial.org/files/?artifact_id=31487 -Lowe \& Woolf: EGU2009-10927, 18:30 Thursday 


\section{Open tool $x x x$}

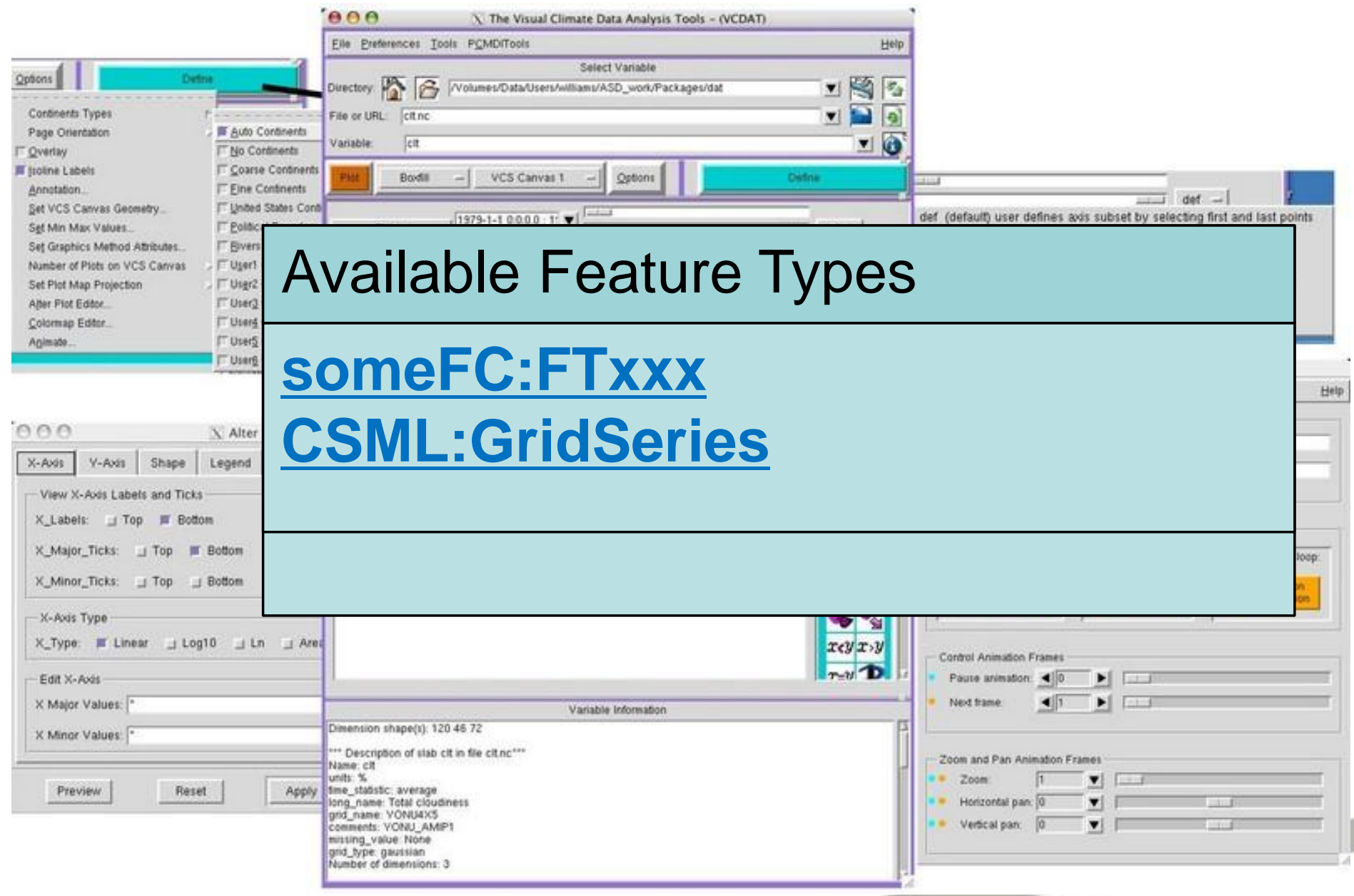

-http://portal.opengeospatial.org/files/?artifact_id=31487 -Lowe \& Woolf: EGU2009-10927, 18:30 Thursday 


\section{Open tool $x x x$}

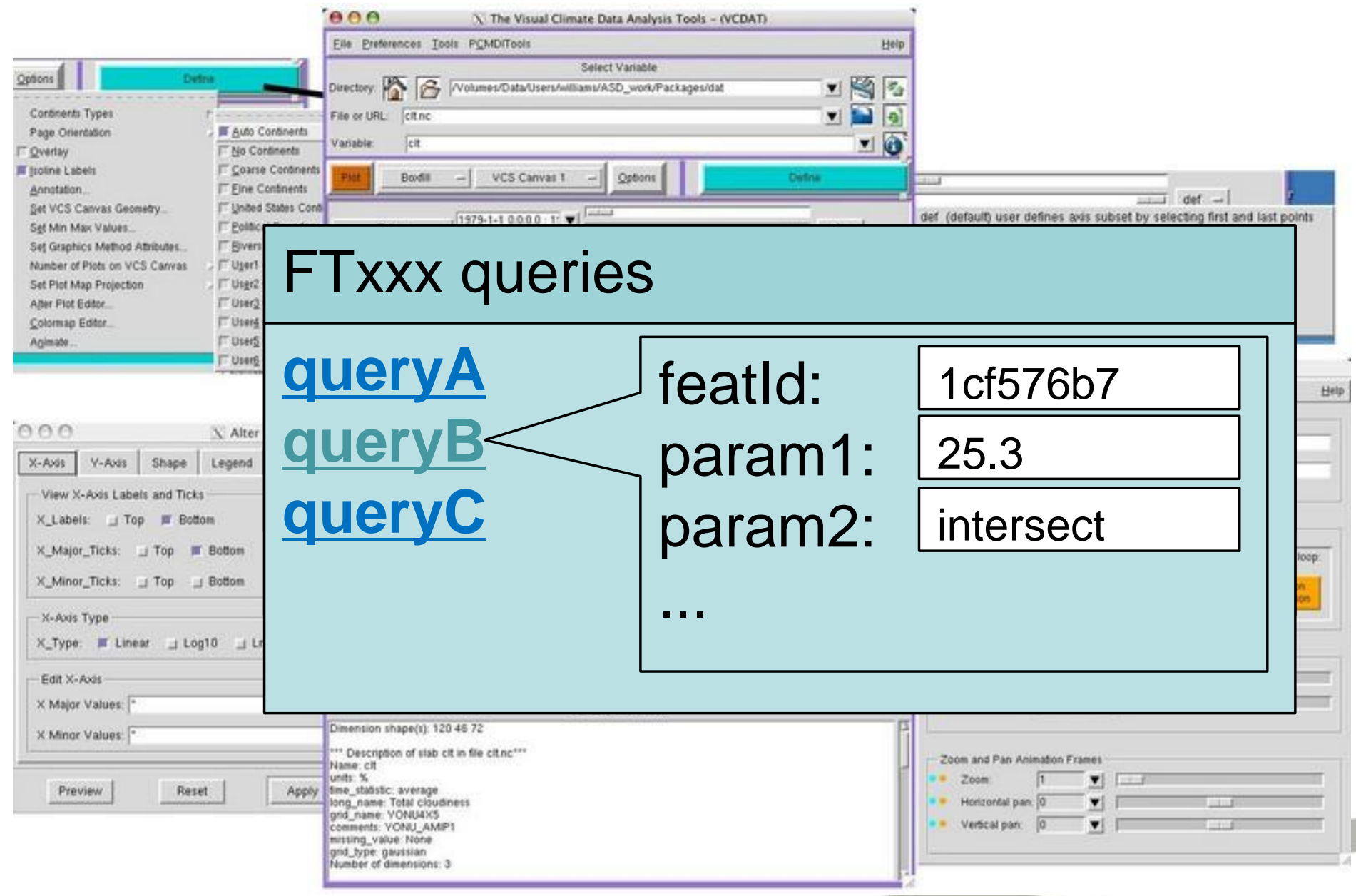

-http://portal.opengeospatial.org/files/?artifact_id=31487 -Lowe \& Woolf: EGU2009-10927, 18:30 Thursday 


\section{Open tool $x x x$}

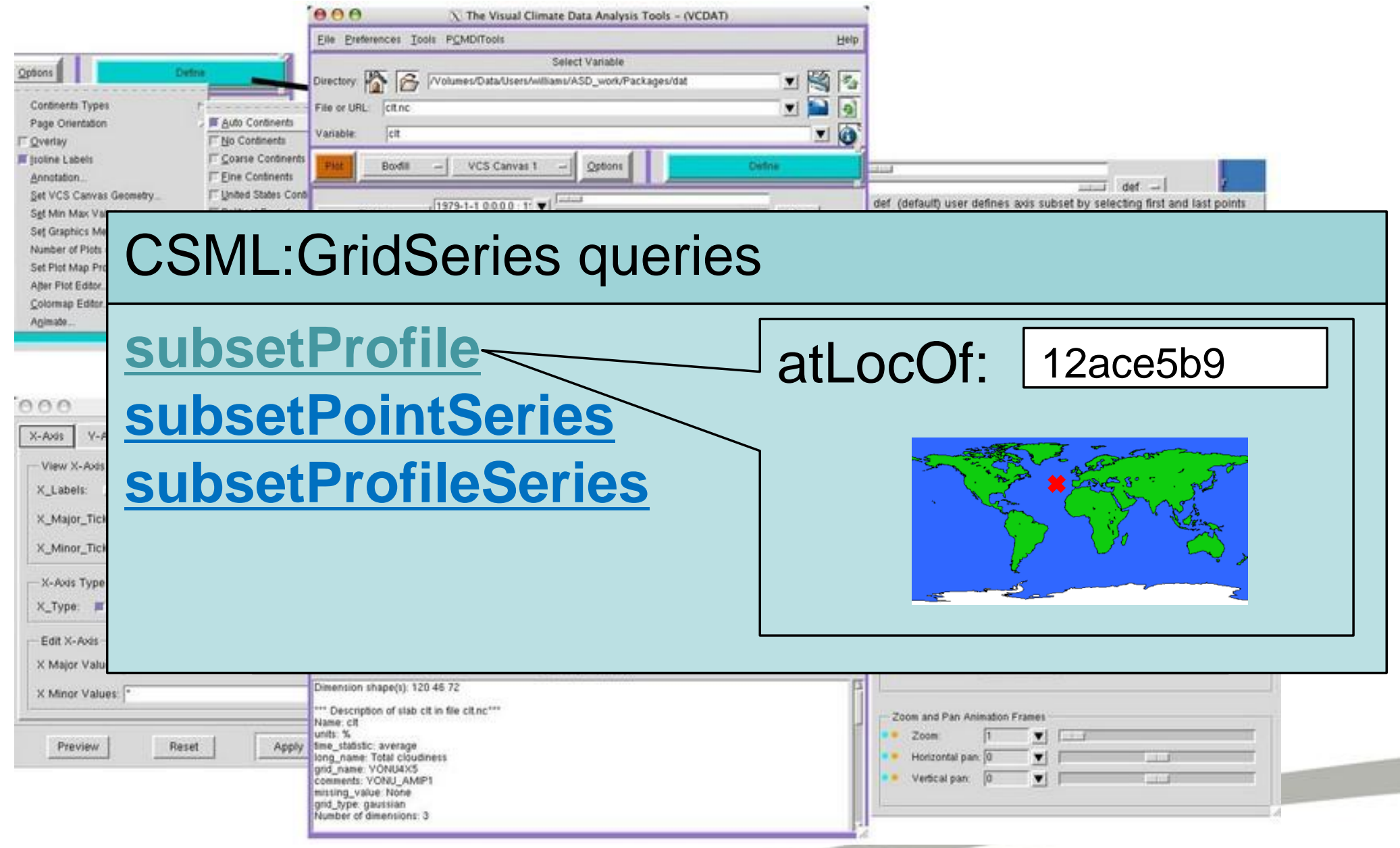

-http://portal.opengeospatial.org/files/?artifact_id=31487 -Lowe \& Woolf: EGU2009-10927, 18:30 Thursday 


\section{WFS - encoding}

- ISO/TS 19129 "Imagery, gridded and coverage data framework"

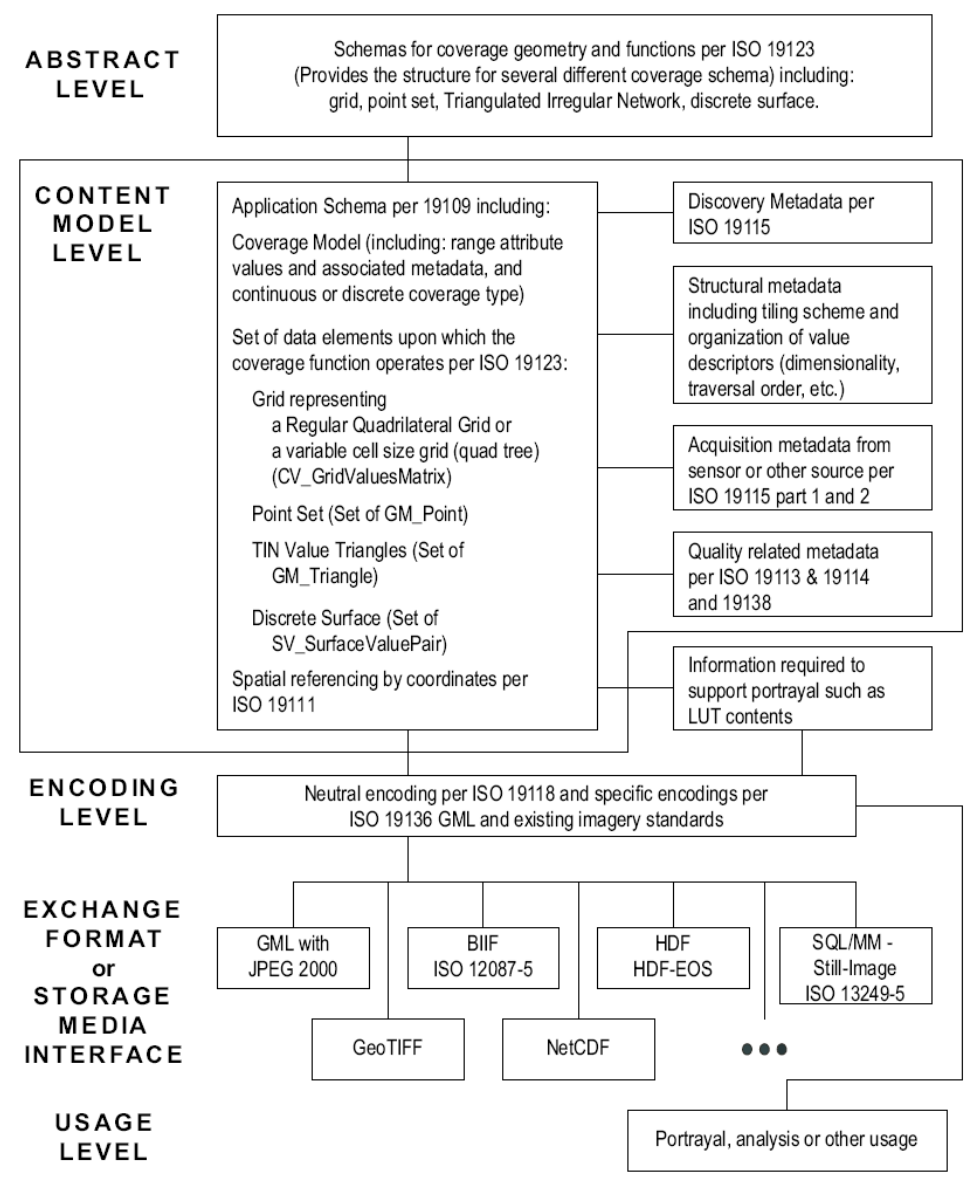

-Distinguishes logical content from exchange format and mappings between them ( $\mathbf{G M L}$ can mediate)

- Application schema also for coverage-based data 


\section{Encoding}

- Model ('GML wrapper'):

- GML feature ‘skeleton' (e.g. CSML)

- Binary file 'flesh' (e.g. netCDF)

- xlink for mappings

- xlink:href = file resource

- xlink:role $=$ nature of resource ('CF-netCDF')

- xlink:arcrole = nature of xlink ('embed content')

-OGC 07-083: "Use of xlink in GML - Profile for filebased data content" link -INSPIRE D2.7: "Guidelines for the encoding of spatial data", Annex C (Encoding of file-based data) link 


\section{Encoding}

-What about irregular grids?

- Need GML implementation of ISO 19123

CV_ReferenceableGrid

- OGC 06-160: our original proposal

- OGC 07-040: Galdos alternative

- OGC 07-112: combined proposal link

- Compatible with CF-netCDF 'coordinate variables'

- Currently being considered by GML SWG

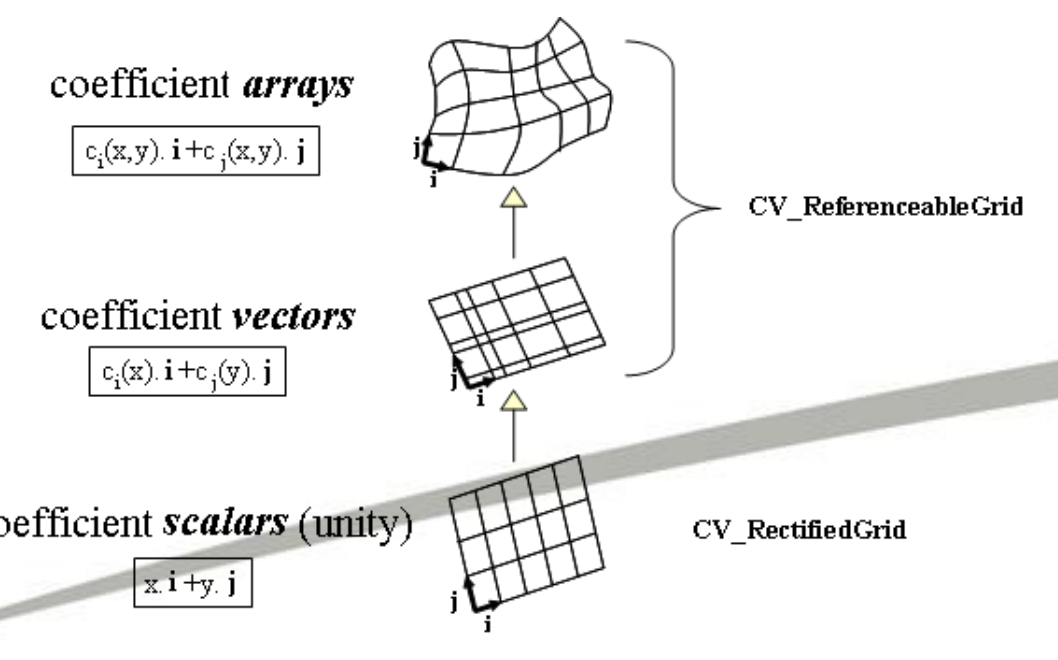




\section{Climatological parameters?}

- SWE Common 'Property model'

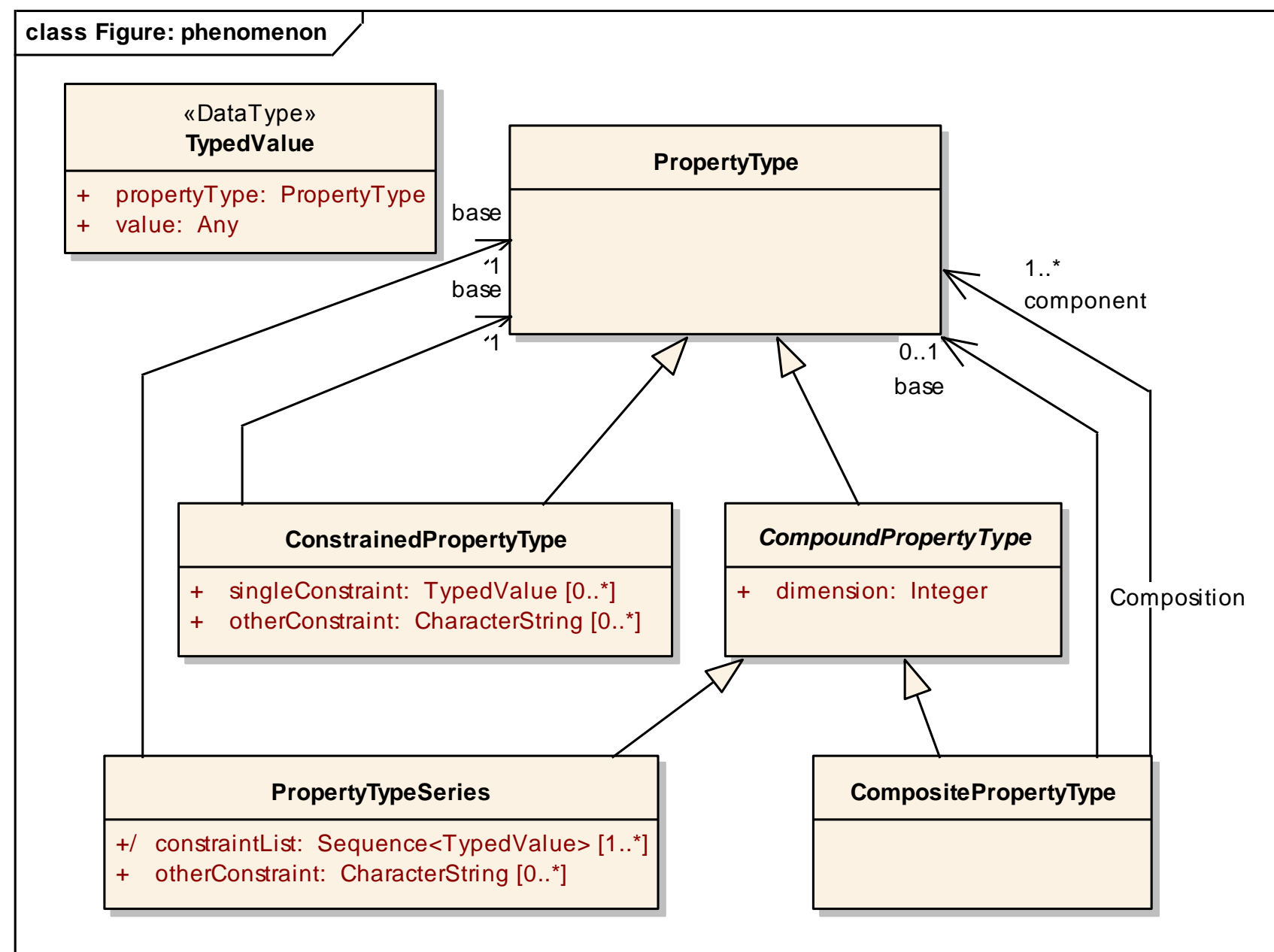




\section{Climatological parameters?}

- SWE Common 'Property model'

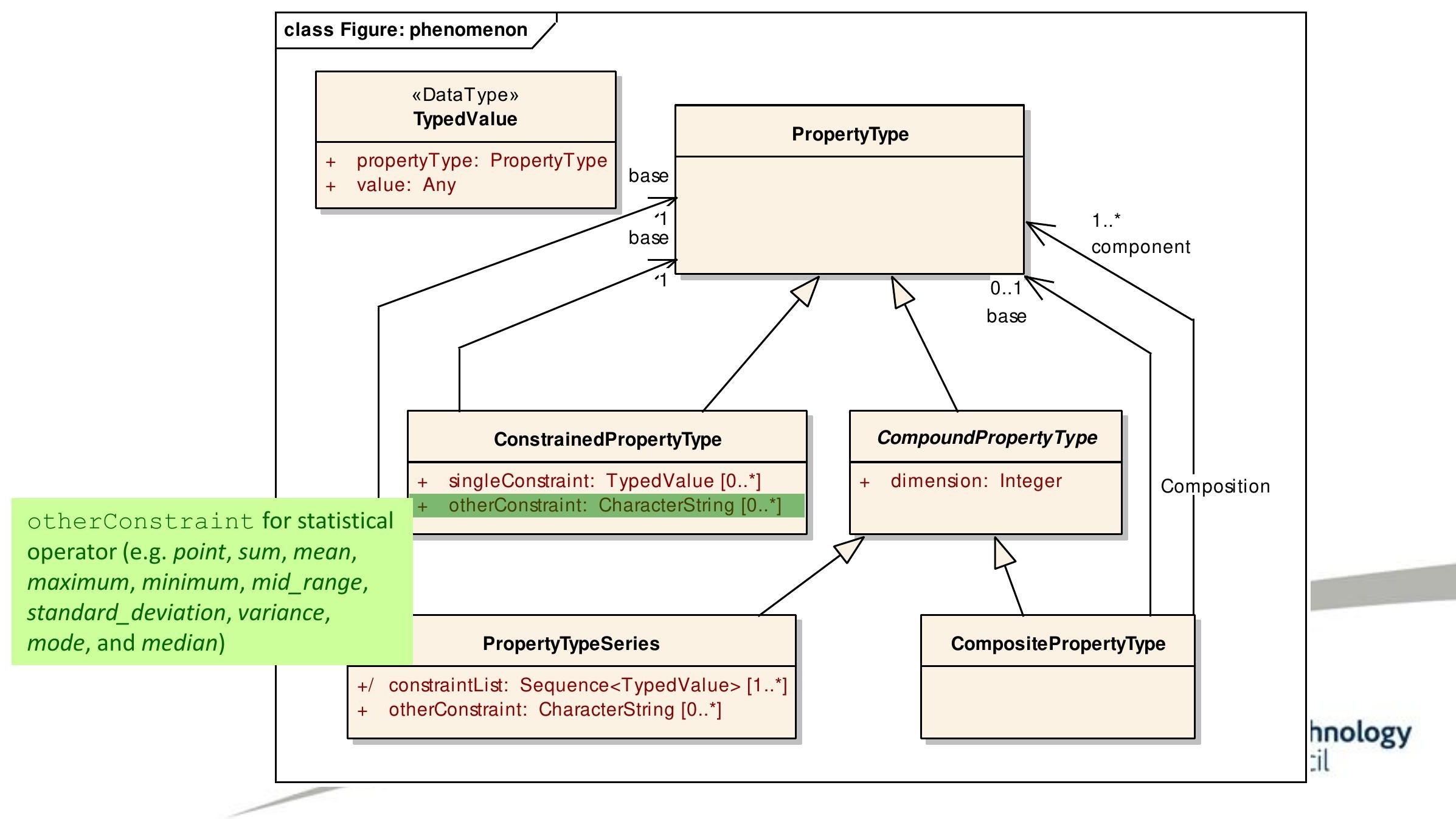




\section{Climatological parameters?}

\section{- SWE Common 'Property model'}

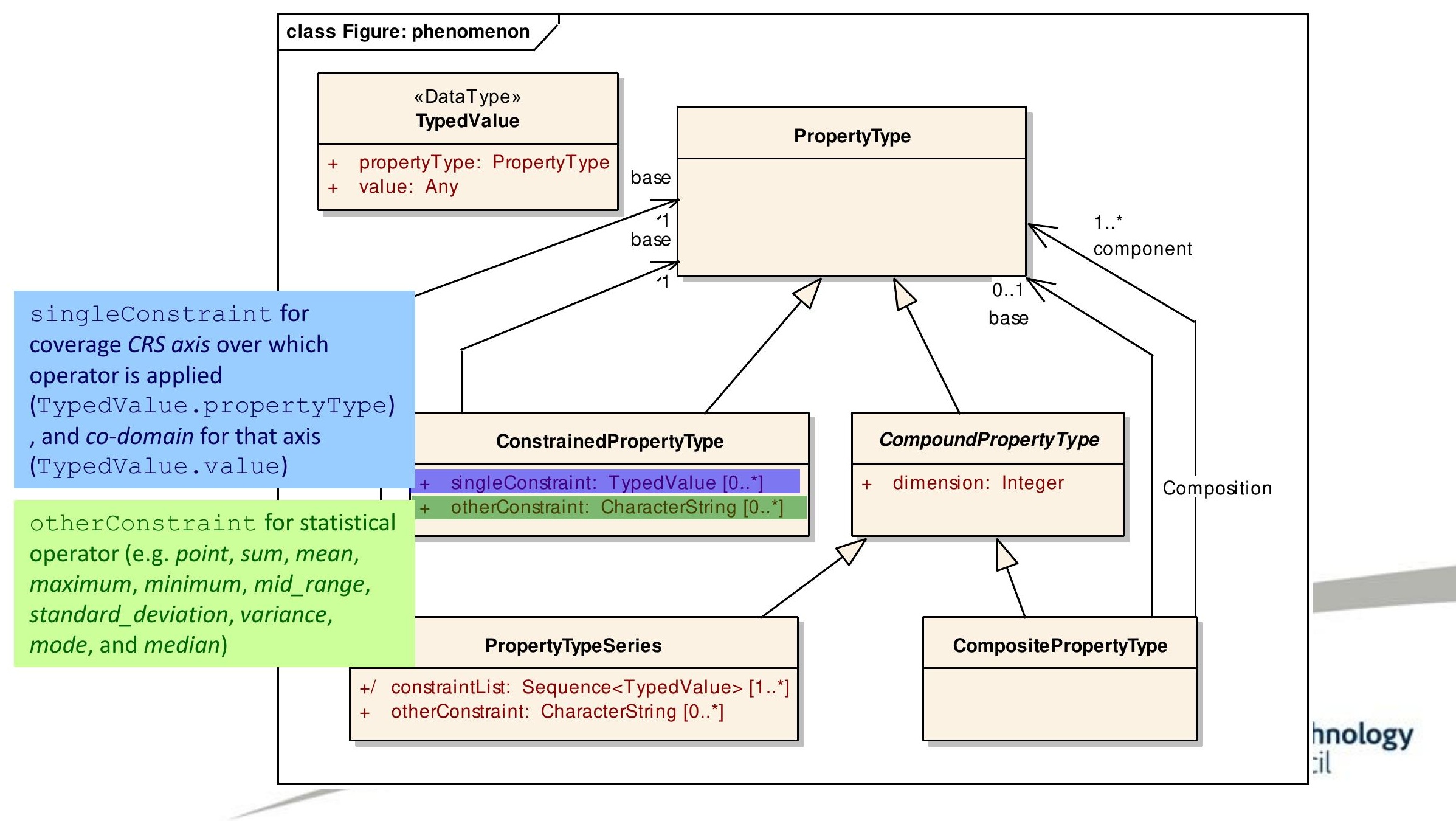




\section{Climatological parameters?}

\section{- E.g. January 2007 maximum temperature}

<swe:ConstrainedPhenomenon gml:id="Jan2007MaxTemp">

<gml:identifier codeSpace="http://ndg.nerc.ac.uk">January 2007 maximum temperature $<$ gml:identifier $>$

<swe:base xlink:href="urn:ndg:cf:air_temperature"/>

$<$ swe:otherConstraint>maximum</swe:otherConstraint>

$<$ swe:singleConstraint>

$<$ swe:TypedValues

<swe:property codeSpace="http://ndg.nerc.ac.uk">time</swe:property>

<swe:value>2007-01-01/2007-01-31</swe:value>

$</$ swe:TypedValues

$</$ swe:singleConstraints

$</$ swe:ConstrainedPhenomenon> 


\section{Climatological parameters?}

\section{- E.g. January 2007 maximum temperature}

<swe:ConstrainedPhenomenon gml:id="Jan2007MaxTemp">

<gml:identifier codeSpace="http://ndg.nerc.ac.uk">January 2007 maximum temperature</gml:identifier>

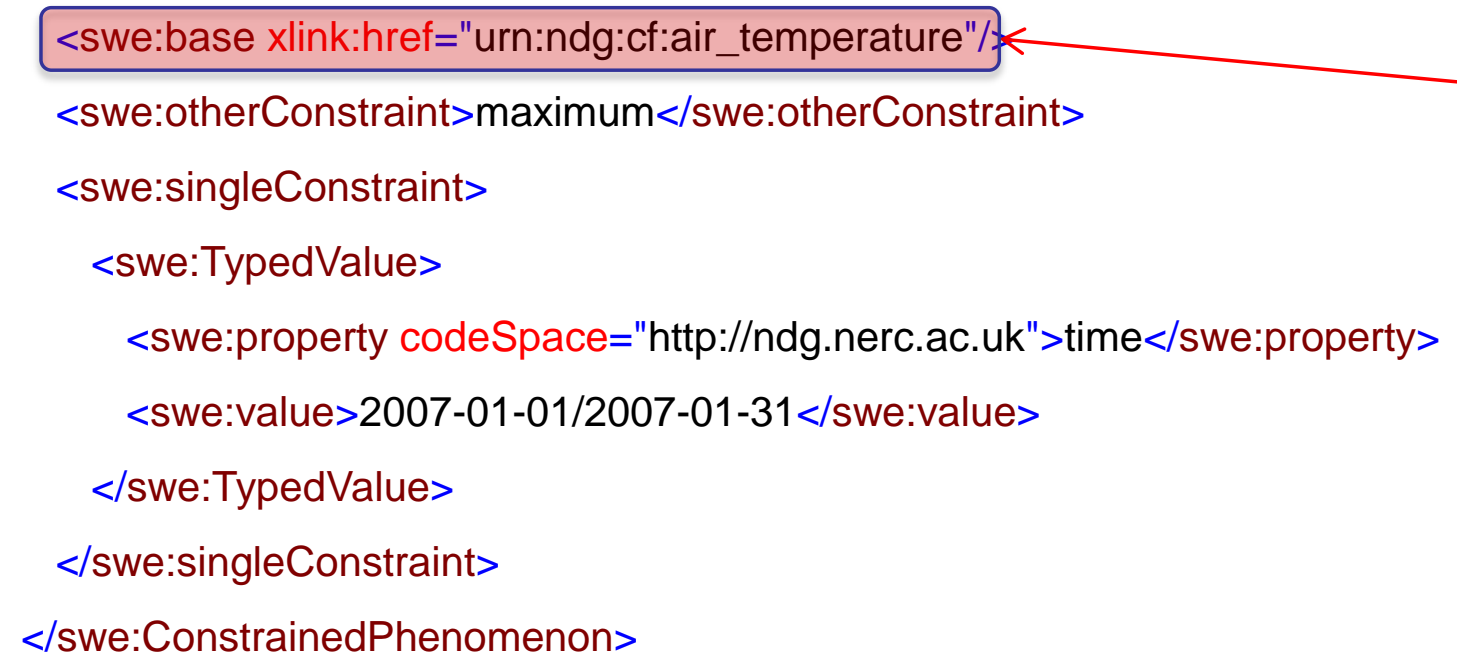




\section{Climatological parameters?}

\section{- E.g. January 2007 maximum temperature}

<swe:ConstrainedPhenomenon gml:id="Jan2007MaxTemp">

<gml:identifier codeSpace="http://ndg.nerc.ac.uk">January 2007 maximum temperature</gml:identifier>

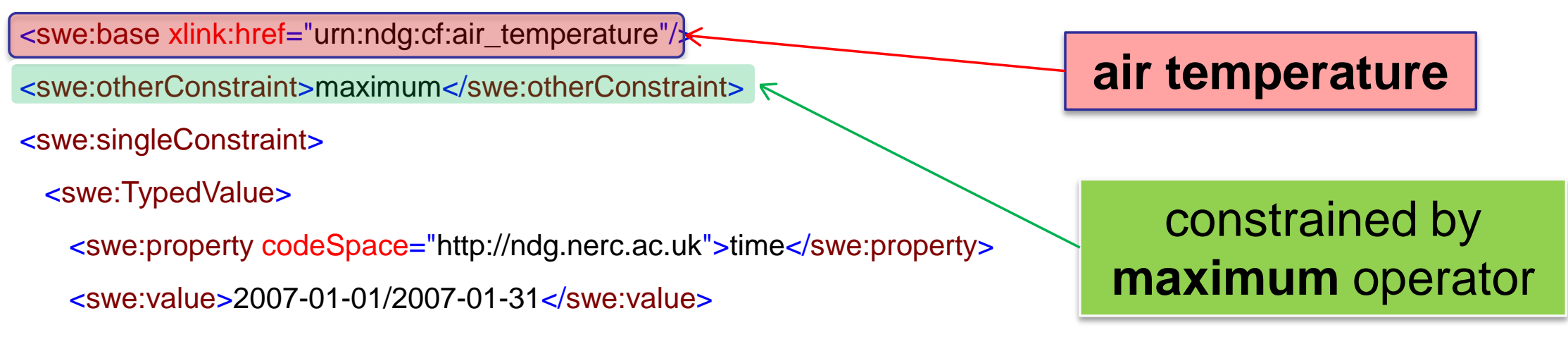

$</$ swe:TypedValues

$</$ swe:singleConstraints

$</$ swe:ConstrainedPhenomenon> 


\section{Climatological parameters?}

\section{- E.g. January 2007 maximum temperature}

<swe:ConstrainedPhenomenon gml:id="Jan2007MaxTemp">

<gml:identifier codeSpace="http://ndg.nerc.ac.uk">January 2007 maximum temperature</gml:identifier>

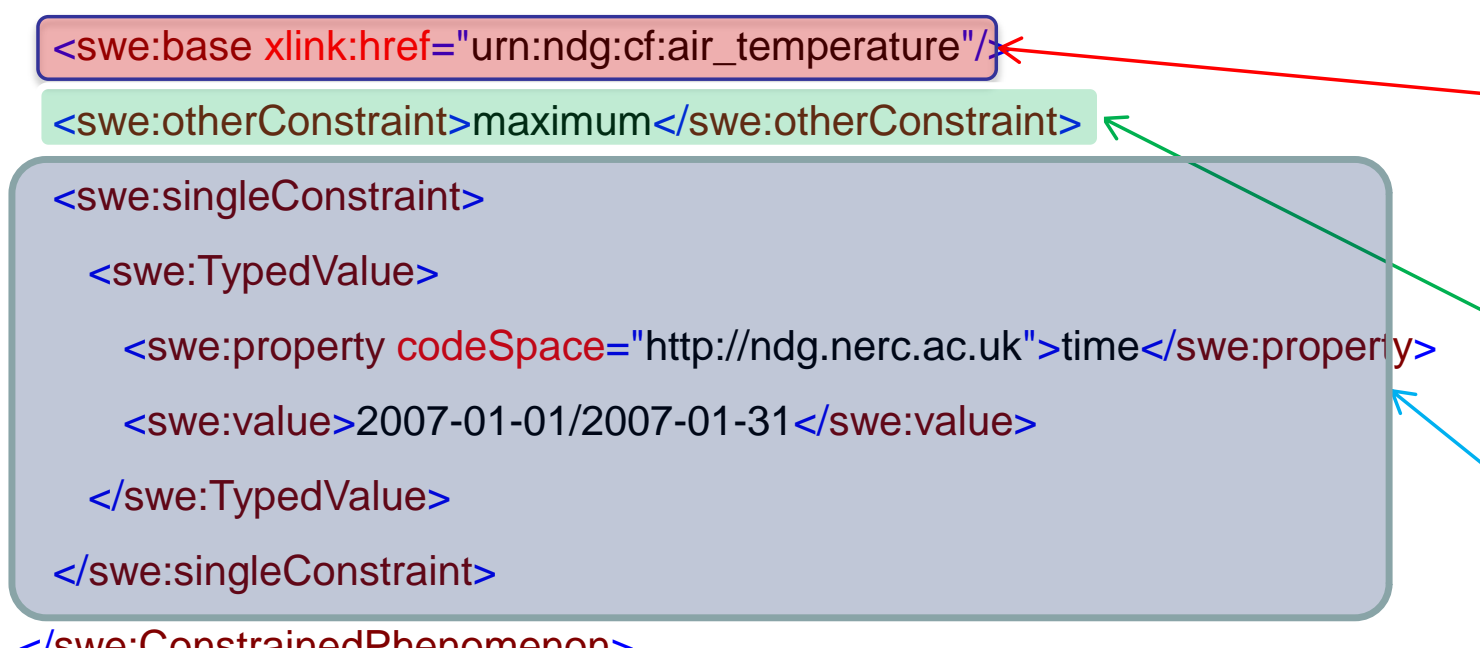

\section{air temperature}

$<$ swe:ConstrainedPhenomenon> 


\section{Climatological parameters?}

-What about 'climatological calendars'?

- induce a 'multi-component' range

- summer (DJF), autumn (MAM), winter (JJA), spring (SON)

- Jan, Feb, Mar, Apr, May, Jun, Jul, Aug, Sep, Oct, Nov, Dec

- 00:00, 01:00, 02:00, 03:00, ..., 21:00, 22:00, 23:00

- how to model them?

- TM_OrdinalReferenceSystem with set of component TM_OrdinalEras for climatological intervals

- TM_OrdinalEras topologically connected

DJF MAM JJA SON




\section{Geog}

\section{temperature}

ERA40

The ECMWF ERA-40 Re-Analysis Project consists of a number of climate datasets spanning the period mid-1957 to August 2002 using a consistent model. The data overlaps with the earlier ECMWF ERA-15 Re-analysis project (1979-1993). The broad objectives and partner organisations are presented in the ERA-40 background information.

\section{European Synoptic stations}

\section{0-1996}

Hourly Surface data from 141 European stations for the period 19901996. Parameters include temperature, wind, rainfall, cloud cover etc.
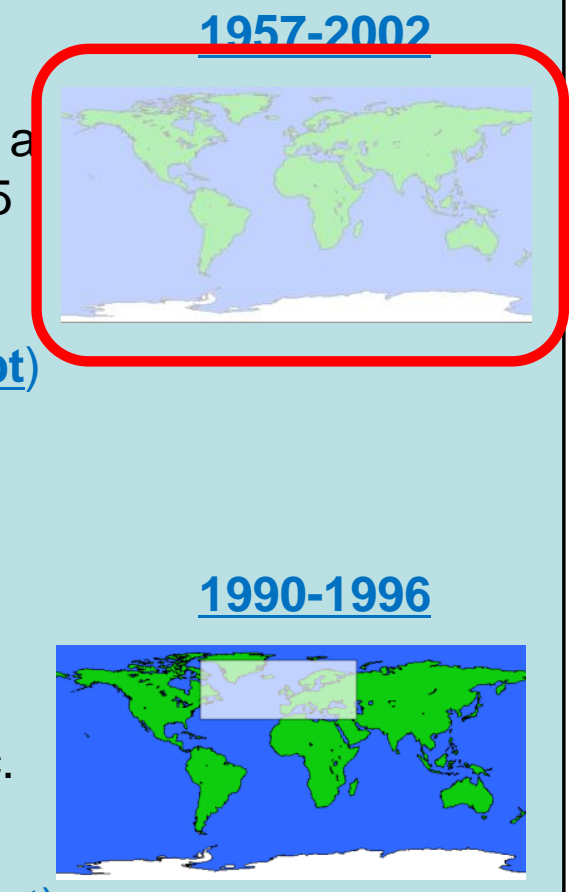


\section{temperature}

ERA40

The ECMWF ERA-40 Re-Analysis Project consists of a number of climate datasets spanning the period mid-1957 to August 2002 using a consiste Re-ana applicationProfile: WMS badc.nerc.ac linkage: right click/copy id information. organis
badc.erc.ac linkage: right click/copy
dinfidsermation.
(xypt

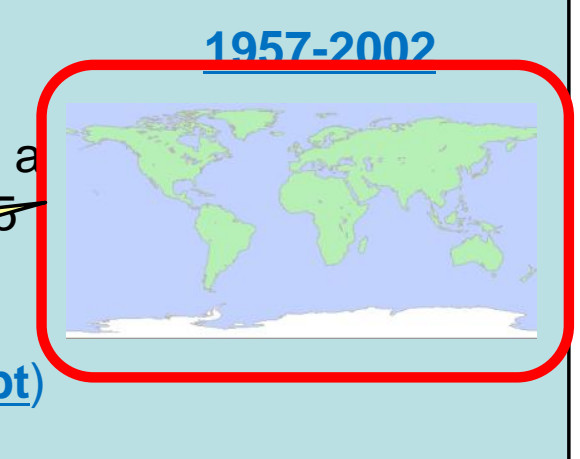

\section{European Synoptic stations}

1990-1996

Hourly Surface data from 141 European stations for the period 19901996. Parameters include temperature, wind, rainfall, cloud cover etc.

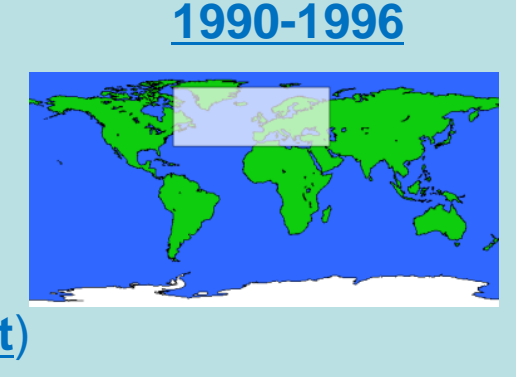




\section{View services}

- Non-standard slices:

- vertical

- $\mathrm{BBOX}=110,-45,190,-45,1000,1000 \& E L E V A T I O N=100 / 950$

- Hovmüller

- $\mathrm{BBOX}=110,-45,190,-45,1000,1000 \&$ TIME=2004-0801/2004-08-31

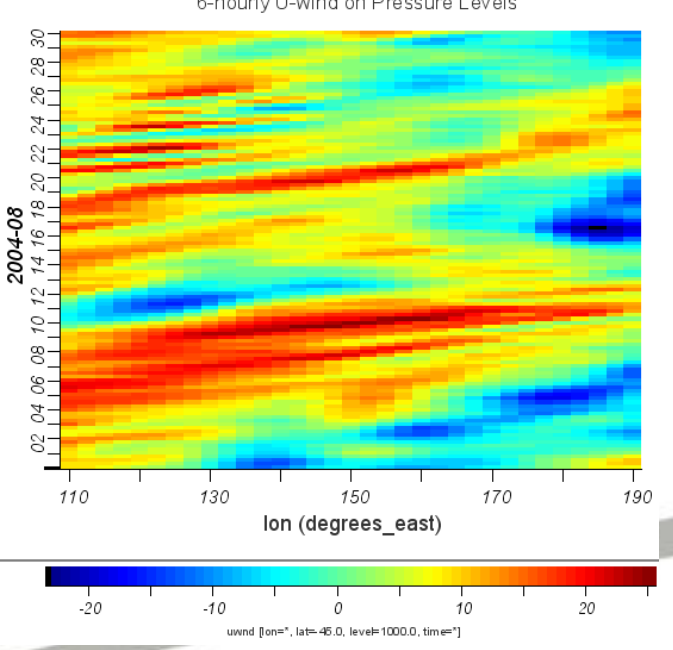




\section{GET MAP OPERATION \\ 3.1. Get Map Request \\ View services}

\subsubsection{Get Map request parameters}

The Get Map request parameters listed in Table 5 shall be provided

\section{INSPIRE IR}

Table 5

\begin{tabular}{|l|l|}
\hline Parameter & Description \\
\hline Layers & List of layer names to be included in the map. \\
\hline Styles & List of style to be used for each layer. \\
\hline Coordinate Reference System & Coordinate Reference System of the map. \\
\hline Bounding box & $\begin{array}{l}\text { The } 4 \text { corner Coordinate of the two dimensional map for the } \\
\text { selected Dimension pair and in the selected Coordinate Reference } \\
\text { System }\end{array}$ \\
\hline Image width & The map width in pixels \\
\hline Image height & The map height in pixels \\
\hline Image format & The output image format. \\
\hline Language & For example a geographical dimension and time \\
\hline Dimension Pair & The two dimensional axis to be used for the map \\
\hline
\end{tabular}

Draft COMMISSION REGULATION implementing Directive 2007/2/EC of the European Parliament and of the Council as regards the network services link 


\section{View services}

\section{- INSPIRE draft IR}

Our comments on v2:

Suggest adding the following text: "For three-dimensional and/or temporally-varying data, the view service shall support geometry selection over a vertical or temporal axis. NOTE: The WMS interface allows such geometry selection. E.g. a vertical slice can be generated using the ELEVATION parameter and a BBOX such as $B B O X=X, y 0, X, y 1$ (for a $y-z$ slice); an $x-t$ slice could be generated, for instance, using TIME=t1/t2 and $B B O X=x 0, Y, x 1, Y$."

\begin{tabular}{|l|c|c|}
\hline INSPIRE & Reference: D3.7.2 Draft Implementing Rule View Service v3.0 \\
\hline & $2008-10-29$ & Page 9 of 14 \\
\hline
\end{tabular}

\subsubsection{Temporal data dimension}

Following Article 8.2.d of the directive, the View Service shall address the temporal aspect of the data. Therefore for data themes with a temporal component the View Service shall allow visualizing the temporal dimension. Different ways of supporting are possible (using the time line to browse through temporal snapshots of 2-D representations of the data theme, allowing time slices along the $x$-t, $y$-t or the $z$-t axis and presenting the result as a 2-D representation...).

\subsubsection{Other dimensions selection and display}

For three-dimensional data, the View Service shall support selection over a third dimension axis. 


\section{Summary}

- Powerful new functionality becoming available through standards

- metadata interoperability

- data interoperability

- common data model

- common query model

- standardised encodings

- service interoperability 


\section{Questions?}

- A. Woolf et. al., "Standards-based data interoperability for the climate sciences", Met. Apps. 12(1), 9-22 (2005)

- D Lowe et. al., "Standards Challenges in the Climate Sciences", AGU Fall Meeting, San Diego, Dec 2006., Eos Trans. AGU, 87(52), Fall Meet. Suppl., Abstract IN43C-0916

- A Woolf et. al., "Data integration with the Climate Science Modelling Language", Adv. in Geosci. 8(1), 83-90 (2006)

- K Millard et. al., "Developing feature types and related catalogues for the marine community: lessons from the MOTIIVE project", Int. J. Spatial Data Infrastructures Res. 2, 132-162

- A Woolf et. al., "Feature types as an integration bridge in the climate sciences", AGU Fall Meeting, San Diego, December 2006, Eos Trans. AGU, 87(52), Fall Meet. Suppl., Abstract IN53C-02 